\title{
Effect of Euphorbia supina Extract on Antioxidant Activity
}

\author{
Hyang Mi Choi and Sun Young Lim*
}

Division of Marine Environment \& Bioscience, Korea Maritime and Ocean University, Republic of Korea

\begin{abstract}
We investigated the effect of Euphorbia supina extract on the production of cellular reactive oxygen species (ROS) in order to evaluate its antioxidative activity. The $\mathrm{H}_{2} \mathrm{O}_{2}$-induced ROS generation was measured with dichlorofluorescein-diacetate (DCFH-DA) assay. The acetone+methylene chloride (A+M) and methanol $(\mathrm{MeOH})$ extracts dose-dependently decreased ROS production induced by $\mathrm{H}_{2} \mathrm{O}_{2}$ compared to the extract-free control during the 120 min assay. The $\mathrm{MeOH}$ extract showed a higher inhibitory effect on the $\mathrm{A}+\mathrm{M}$ at all concentrations tested. All tested fractions showed a decrease in ROS production with increase in concentration. Treatments with $n$-hexane and $85 \%$ aqueous methanol $(\mathrm{MeOH})$ fractions $(0.5 \mathrm{mg} / \mathrm{mL}$ concentrations) showed $82 \%$ and $97 \%$ inhibition rate, respectively, suggesting that the $85 \%$ aqueous $\mathrm{MeOH}$ fraction had ROS scavenging effects. These results indicate that the $85 \%$ aqueous $\mathrm{MeOH}$ fraction inhibited cellular oxidation and may contain valuable active compounds.
\end{abstract}

Keywords: Antioxidant, cellular oxidation, Euphorbia supina, reactive oxygen species.

\section{INTRODUCTION}

Euphorbia supina is an annual summer broadleaf weed and spotted spurge belonging to the Euphorbiaceae family. This broadleaf weed is often found in disturbed sites, such as poorly maintained lawns, waste areas, cultivated ground, and glades, and along sidewalks, railroads, and roadsides. The stems and foliage exude a milky sap when injured, and the stems are pinkish in color and densely hairy [1]. In Korea, $E$. supina has traditionally been known to be effective in treating bronchitis, jaundice, and hemorrhage [2, 3]. Euphorbia species are known to possess biologically active compounds [4]. For example, jatrophane diterpenoids from E. pubescens [5], E. fischeriana [6], E. dendroides [7], and E. turcezaninowii [8] have been shown to act as regulators of multidrug resistance. Some studies identified several key polyphenol components from E. supina, which were suggested to be highly associated with the antioxidant activity of this species $[9,10]$. The findings of previous study showed that $E$. supina contained linolenic acid (18:3n3 ) and suggested that this fatty acid might be related to the various biological activities of this plant [11]. Thus, we investigated the potential biological benefits of $E$. supina extracts, including its antioxidant properties, cytotoxicity against human cancer cell lines, and modulation of immune processes.

Reactive oxygen species (ROS) include both radical and non-radical substances. Radical ROS include hydroxyl, superoxide, peroxy, and alkoxy radicals, where non-radical ROS include hydrogen peroxide and single oxygen. Cellular ROS are known to play an important role in affecting human

*Address correspondence to this author at the Division of Marine Environment \& Bioscience, Korea Maritime and Ocean University, Republic of Korea; Tel; +82-51-410-4757; Fax: +82-51-404-475;

E-mail: sylim@kmou.ac.kr health by causing several chronic diseases, such as cancer, inflammation, aging, asthma, hypertension and cardiovascular diseases [12]. These ROS are generated during normal cell metabolism [13]. To scavenge cellular ROS, intake of antioxidants from foods or supplements is recommended. Some studies suggest that diets rich in medical plants and marine organisms protect against ROSinduced oxidative stress since they contain several types of bioactive compounds with antioxidant activity [14, 15]. Thus, in the present study, we investigated the antioxidant activity of E. supina, which grows wild in Korea, in order to determine its potential as a natural antioxidant supplement.

\section{MATERIALS AND METHODS}

\section{Materials and Cell Culture}

Dulbeco's modified Eagle's medium (DMEM), fetal serum albumin (FBS), phosphate buffered saline (PBS), dimethylsulfoxide (DMSO), penicilline-strectomycine, 2'-7' dichlorofluorescein-diacetate (DCFH-DA) were obtained from Sigma-Aldrich (St. Louis, MO). Human fibroblast cell line HT-1080 was obtained from the Korea Cell Line Bank. The cells were maintained at $37^{\circ} \mathrm{C}$ under $5 \% \mathrm{CO}_{2}$ in DMEM containing $10 \% \quad$ FBS and 100 units $/ \mathrm{mL}$ penicillinstreptomycin.

\section{Extraction and Fractionation}

E. supina samples were collected from lawns and sidewalks in Korea Maritime and Ocean University, Busan city, Korea on July-August, 2013. The sample was authenticated by Professor Moo Ryong Huh who is a plant taxonomist in Gyeongsang National University. E. supina samples were dried in dark area, finely cut and used for the plant material. Dried E. supina samples $(520 \mathrm{~g})$ were extracted twice with acetone+methylene chloride $(\mathrm{A}+\mathrm{M})$ and 
methanol $(\mathrm{MeOH})$. The combined crude extracts were fractionated with $n$-hexane and $85 \%$ aqueous $\mathrm{MeOH}$, and the aqueous layer was also further fractionated with $n$-butanol $(n-\mathrm{BuOH})$ and water, resulting in the $n$-hexane $(5.6 \mathrm{~g}), 85 \%$ aqueous $\mathrm{MeOH}(2.7 \mathrm{~g}), n-\mathrm{BuOH}(6.7 \mathrm{~g})$ and water $(1.9 \mathrm{~g})$ fractions. The crude extracts and four types of fractions with different polarities were concentrated to dryness and the residues were kept at $4^{\circ} \mathrm{C}$.

\section{Intracellular ROS Measurement}

Cellular oxidative stress owing to ROS generation from $\mathrm{H}_{2} \mathrm{O}_{2}$ was measured by DCFH-DA method [16]. DCFH-DA is diffused through the cell membrane and is enzymatically hydrolyzed by intracellular esterases to nonfluorescent DCFH, which is rapidly oxidized to the highly fluorescent DCF in the presence of ROS. HT-1080 cells were first cultured in 96-well plates $\left(5 \times 10^{5} /\right.$ well) for $24 \mathrm{~h}$. After washing with PBS, cells were treated with $20 \mu \mathrm{M}$ DCFH-DA and pre-incubated for $20 \mathrm{~min}$. Then samples were treated and incubated for $1 \mathrm{~h}$. After DCFH-DA was removed and washed with PBS, $500 \mu \mathrm{M} \mathrm{H}_{2} \mathrm{O}_{2}$ was added and incubated for $120 \mathrm{~min}$. DCF fluorescence intensity was measured with

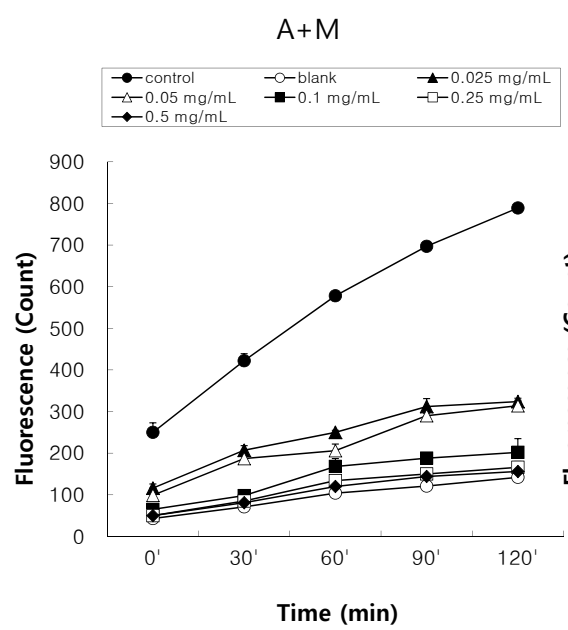

an excitation wavelength at $485 \mathrm{~nm}$ and emission wavelength at $535 \mathrm{~nm}$, using a fluorometric plate reader (VICTRO3, Perkin Elmer, Wellesley, MA).

\section{Statistical Analysis}

Data were presented as mean \pm standard error of the mean (SEM). ANOVA was used to determine the significance of the treatments using the SIGMASTAT Statistical program package (Jandel Co., Erkrath, Germany): Comparisons of the treatment mean were done with the use of Tukey's post-hoc test at $5 \%$ level of significance.

\section{RESULTS AND DISCUSSION}

\section{Effect of Extracts and Fractions of $E$. supina on the Production of Cellular ROS}

The inhibitory effects of extracts of E. supina on ROS production induced by $\mathrm{H}_{2} \mathrm{O}_{2}$ in $\mathrm{HT}-1080$ cells are presented in Fig. (1). The $\mathrm{A}+\mathrm{M}$ and $\mathrm{MeOH}$ extracts dose-dependently decreased ROS induced by $\mathrm{H}_{2} \mathrm{O}_{2}$ compared to the levels seen in the control without the extracts during $120 \mathrm{~min}$. Treatments with $\mathrm{A}+\mathrm{M}$ and $\mathrm{MeOH}$ extracts $(0.5 \mathrm{mg} / \mathrm{mL}$ concentrations) reduced ROS generation by $98 \%$ (Table 1).

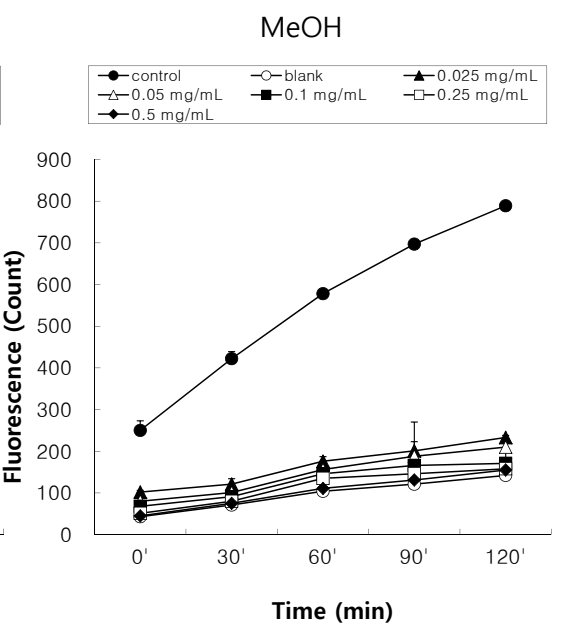

Fig. (1). Effect of acetone+methylene chloride $(\mathrm{A}+\mathrm{M})$ and methanol $(\mathrm{MeOH})$ extracts from E. supina on the levels of reactive oxygen species in HT-1080 cells. Control, sample was treated with $500 \mu \mathrm{M} \mathrm{H}_{2} \mathrm{O}_{2}$ and phosphate buffered saline; Blank, sample was treated with phosphate buffered saline without $\mathrm{H}_{2} \mathrm{O}_{2}$.

Table 1. Effect of extracts and fractions from $E$. supina on the production inhibition (\%) of reactive oxygen species in HT-1080 cells.

\begin{tabular}{|l|l|l|l|l|l|}
\hline \multicolumn{1}{|c|}{ Extracts/Fractions } & \multicolumn{5}{c|}{ Treatment Concentration (mg/mL) } \\
\hline & \multicolumn{1}{|c|}{$\mathbf{0 . 0 2 5}$} & \multicolumn{1}{c|}{$\mathbf{0 . 0 5}$} & \multicolumn{1}{c|}{$\mathbf{0 . 1}$} & \multicolumn{1}{c|}{$\mathbf{0 . 2 5}$} \\
\hline \hline $\mathrm{A}+\mathrm{M}$ & $71.9 \pm 2.5^{\mathrm{a}, 1}$ & $73.4 \pm 3.5^{\mathrm{a}, 1}$ & $90.7 \pm 7.2^{\mathrm{a}, 2}$ & $96.3 \pm 1.5^{\mathrm{a}, 2}$ & $97.8 \pm 2.0^{\mathrm{a}, 2}$ \\
\hline $\mathrm{MeOH}$ & $85.9 \pm 2.2^{\mathrm{a}, 1}$ & $89.5 \pm 2.5^{\mathrm{a}, 1}$ & $95.5 \pm 2.4^{\mathrm{a}, 2}$ & $97.5 \pm 3.1^{\mathrm{a}, 2}$ & $98.0 \pm 3.5^{\mathrm{a}, 2}$ \\
\hline Hexane & $65.4 \pm 1.1^{\mathrm{b}, 1}$ & $72.7 \pm 3.1^{\mathrm{a}, 1}$ & $80.8 \pm 4.3^{\mathrm{a}, 2}$ & $89.0 \pm 1.4^{\mathrm{a}, 2}$ & $91.0 \pm 2.0^{\mathrm{a}, 2}$ \\
\hline $85 \%$ aq. $\mathrm{MeOH}$ & $78.0 \pm 0.7^{\mathrm{a}, 1}$ & $81.9 \pm 0.8^{\mathrm{a}, 1}$ & $86.4 \pm 0.2^{\mathrm{a}, 1}$ & $94.3 \pm 0.7^{\mathrm{a}, 2}$ & $97.4 \pm 0.5^{\mathrm{a}, 2}$ \\
\hline BuOH & $57.3 \pm 1.0^{\mathrm{b}, 1}$ & $61.9 \pm 1.8^{\mathrm{b}, 1}$ & $68.3 \pm 0.9^{\mathrm{b}, 1}$ & $77.5 \pm 1.0^{\mathrm{b} 2}$ & $81.7 \pm 1.6^{\mathrm{b}, 2}$ \\
\hline Water & $39.4 \pm 2.5^{\mathrm{c}, 1}$ & $44.5 \pm 1.8^{\mathrm{c}, 1}$ & $54.4 \pm 4.6^{\mathrm{b}, 2}$ & $59.7 \pm 2.8^{\mathrm{c} 2}$ & $61.0 \pm 1.8^{\mathrm{c}, 2}$ \\
\hline
\end{tabular}

*Values are expressed as mean \pm standard deviation of inhibition rate. Values in the same column with different letters and row with different Arabic numerals are significantly different at $P<0.05$ using Turkey's test. A+M, acetone with methylene chloride extract; $\mathrm{MeOH}$, methanol extract; Hexane, $n$-hexane fraction; $85 \%$ aq. $\mathrm{MeOH}, 85 \%$ aqueous methanol fraction; $\mathrm{BuOH}, n$-butanol fraction; Water, water fraction. 
In particular, the $\mathrm{MeOH}$ extract showed a higher inhibitory effect all tested concentrations compared to the A+M extract. Figs. (2-5) show the inhibitory effect of solvent fractions ( $n$ hexane, $85 \%$ aqueous $\mathrm{MeOH}, n-\mathrm{BuOH}$ and water) on ROS levels. All tested fractions decreased of ROS production in a concentration-dependent manner. Treatments with $n$-hexane, $85 \%$ aqueous $\mathrm{MeOH}$ and $n-\mathrm{BuOH}$ fractions $(0.5 \mathrm{mg} / \mathrm{mL}$ concentrations) resulted in $91 \%, 97 \%$, and $82 \%$ ROS inhibition, suggesting that the $85 \%$ aqueous $\mathrm{MeOH}$ fraction had the strongest effect in reducing ROS production.

Nugroho et al. [17] investigated the peroxynitritescavenging activity of extracts and fractions of $E$. supina and found that the ethylacetate faction exhibited the strongest ONOO- scavenging activity and contained the highest content of polyphenols. They also suggested that the potent activity of this fraction was related to high content of galloylated flavonoid glycosides and ellagic acid, which are believed to strong ONOO- scavengers and are therefore beneficial for the treatment or prevention of gastrointestinal diseases. Hong et al. [9] also found the highest radical scavenging activity in the ethylacetate fraction of E. supina and isolated eight flavonoids from this fration. Heo et al. [18] evaluated the antioxidant activity of an extract of E. humifusa, and found that the methanol extract showed DPPH radical scavenging activity. Another study on E. humifusa indicated that its fractions show antioxidant effects in biological systems, particularly in skin exposed to ultravilet radiation, by scavenging ${ }^{1} \mathrm{O}_{2}$ and other ROS, and inhibit damage to cellular membranes against ROS [19]. Farhan et al. [20] suggested that ethanol and water extracts from E. macroclada schyzoceras are effective antioxidants; some aromatic compounds and fatty acids were detected

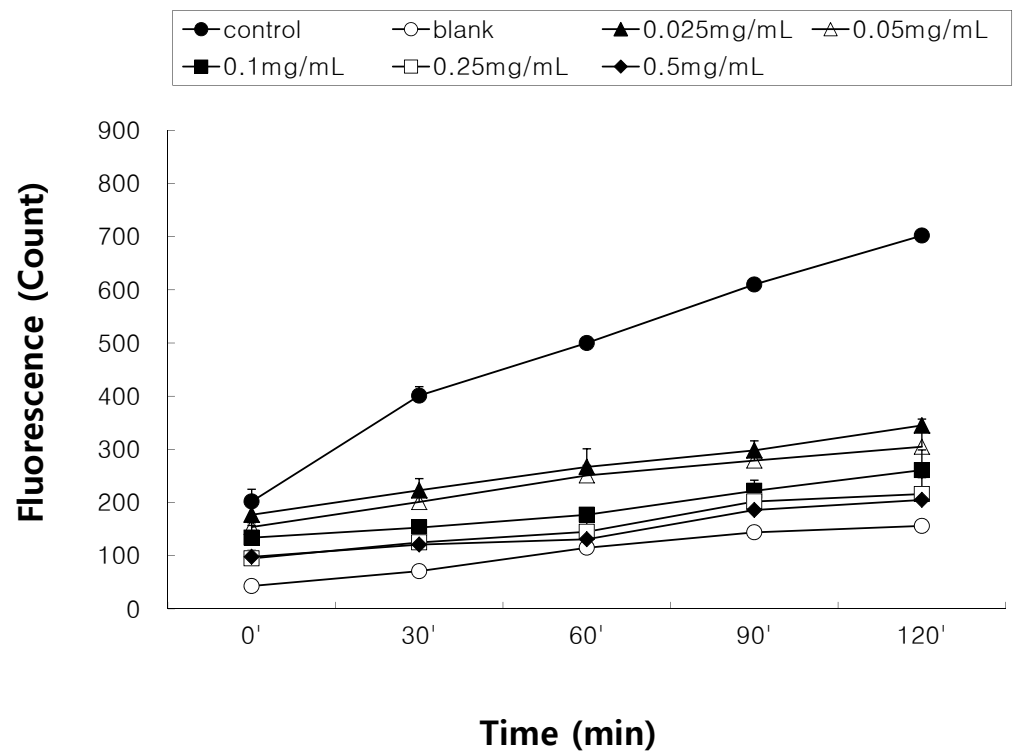

Fig. (2). Effect of $n$-hexane fraction from E. supina on the levels of reactive oxygen species in HT-1080 cells. Control, sample was treated with $500 \mu \mathrm{M} \mathrm{H}_{2} \mathrm{O}_{2}$ and phosphate buffered saline; Blank, sample was treated with phosphate buffered saline without $\mathrm{H}_{2} \mathrm{O}_{2}$.

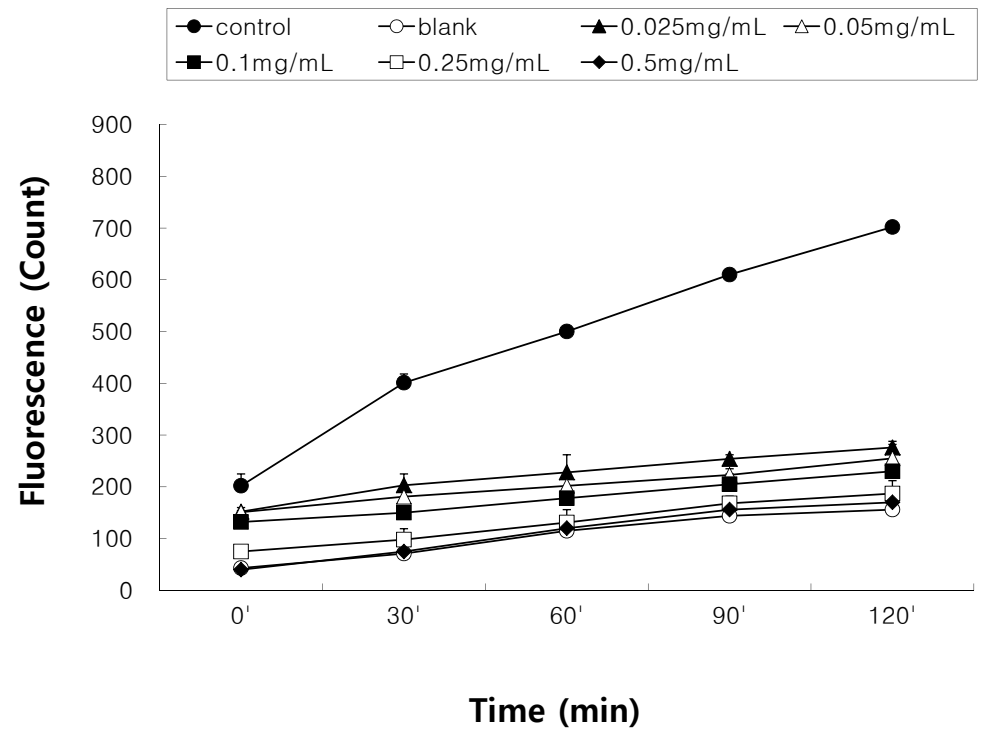

Fig. (3). Effect of $85 \%$ aqueous methanol fraction from E. supina on the levels of reactive oxygen species in HT-1080 cells. Control, sample was treated with $500 \mu \mathrm{M} \mathrm{H}_{2} \mathrm{O}_{2}$ and phosphate buffered saline; Blank, sample was treated with phosphate buffered saline without $\mathrm{H}_{2} \mathrm{O}_{2}$. 


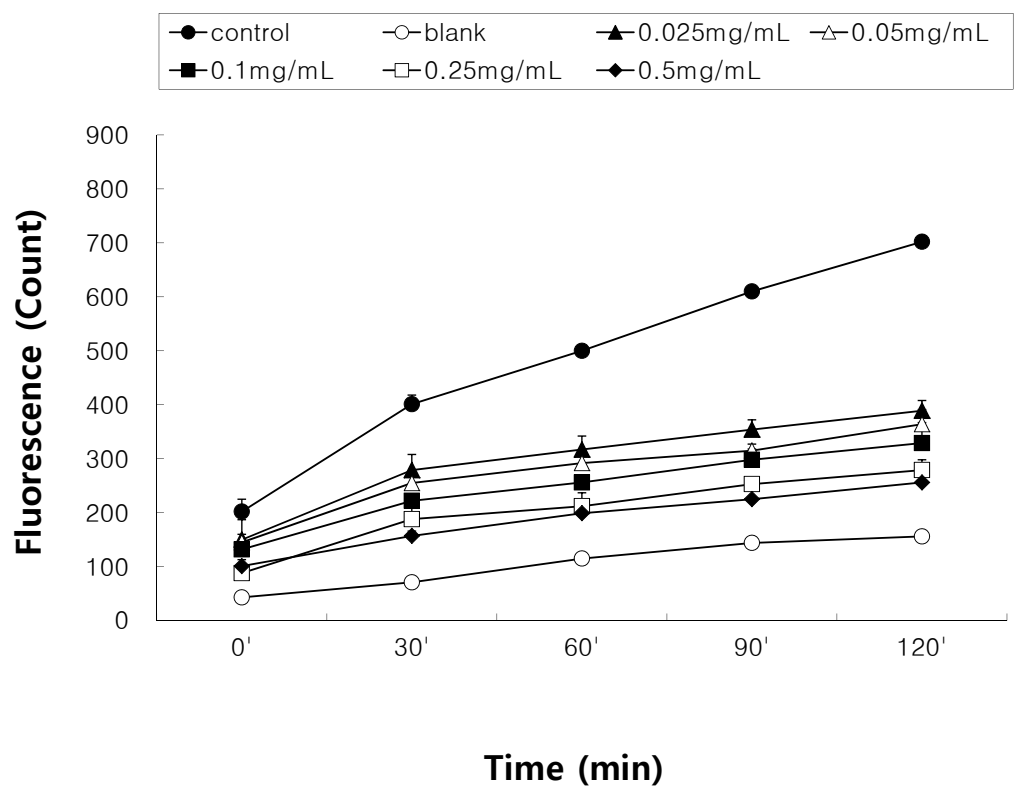

Fig. (4). Effect of $n$-butanol fraction from E. supina on the levels of reactive oxygen species in HT-1080 cells. Control, sample was treated with $500 \mu \mathrm{M} \mathrm{H}_{2} \mathrm{O}_{2}$ and phosphate buffered saline; Blank, sample was treated with phosphate buffered saline without $\mathrm{H}_{2} \mathrm{O}_{2}$.

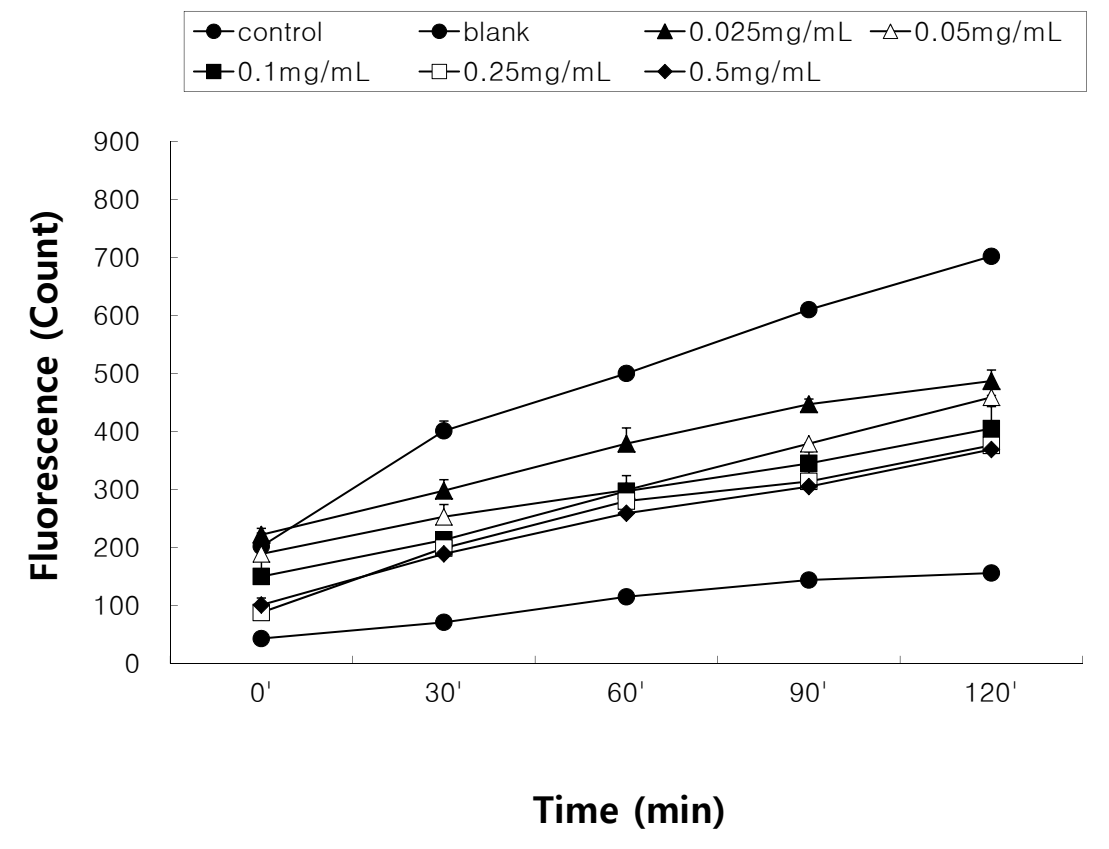

Fig. (5). Effect of water fraction from E. supina on the levels of reactive oxygen species in HT-1080 cells. Control, sample was treated with $500 \mu \mathrm{M} \mathrm{H}_{2} \mathrm{O}_{2}$ and phosphate buffered saline; Blank, sample was treated with phosphate buffered saline without $\mathrm{H}_{2} \mathrm{O}_{2}$.

among the chemical compounds in these extracts. Taken together, these results show that plants of the genus Euphorbia can be used for preventing a number of diseases related to oxidative stress. Our previous study on the fatty acid composition of E. supina demonstrated that among the fractions tested, the $85 \%$ aqueous $\mathrm{MeOH}$ fraction contained the highest percentage of $18: 3 n-3$ and showed a potent inhibitory effect on the proliferation of human cancer cells [11]. In conclusion, the $85 \%$ aqueous $\mathrm{MeOH}$ fraction inhibited cellular oxidation and may therefore contain valuable active compounds. Therefore, analysis of the primary functional components of E. supina demonstrated the antioxidant effects of this plant, indicating its potential to modulate oxidative stress.

\section{CONFLICT OF INTEREST}

The authors confirm that this article content has no conflict of interest. 


\section{ACKNOWLEDGEMENTS}

This research was supported by Basic Science Research Program through the National Research Foundation of Korea (NRF) funded by the Ministry of Education, Science and Technology (NRF-2013R1A1A2004694).

\section{REFERENCES}

[1] Ko KS, Jeon ES. Ferms, ferm-allies and seed bearing plants of Korea. Seoul: Iljin-Sa, 2003.

[2] Cha BC, Kim JA, Lee YS. Cytotoxity activities of Panax ginseng and Euphorbia humifusa in human brain tumor cells. Kor $\mathbf{J}$ Pharmacogn 1996; 27: 350-3.

[3] An RB, Kwon JW, Kown TO, Chung WT, Lee HS, Kim YC. Chemical constituents from the whole plants of Euphorbia supina Rafin. Kor J Pharmacogn 2007; 38: 291-5.

[4] Rechinger KH, Ed. Euphorbiacease. Flora iranica, no. 6. Akademische Druck-u, Verlagsanstalt: Graz, 1982.

[5] Valente C, Pedro M, Duarte A, Nascimento MS, Abreu PM, Ferreira MJ. Bioactive diterpenoids, a new jatrophane and two entabietanes, and other constituents from Euphorbia pubescens. J Nat Proc 2004; 67: 902-4.

[6] Liu LG, Tan RX. New jatrophane diterpenoid esters from Euphobia turczaninowii. J Nat Prod 2001; 6: 1064-8.

[7] Corea G, Fattorusso E, Lanzotti V, et al. Modified jatrophane diterpenes as modulators of multidrug resistance from Euphorbia dendroides L. Bioorg Med Chem 2003; 11: 5221-7.

[8] Liu WK, Ho JC, Qin G, Che CT. Jolkinolide B induces neuroendocrine differentiation of human prostate $\mathrm{LNCaP}$ cancer cell line. Biochem Pharmacol 2002; 63: 951-7.

[9] Hong HK, Kwak JH, Kang SC, et al. Antioxidant constituents from the whole plants of Euphorbia supine. Kor J Pharmacogn 2008; 39: 260-4.
[10] Song Y, Jeong SW, Lee WS, et al. Determination of polyphenol components of Korean prostate spurge (Euphorbia supine) by using liquid chromatography-tandem mass spectrometry: overall contribution to antioxidant activity. J Analytical Methods Chem 2014; Article ID 418690. Internet: http://dx.doi.org/10.1155/2014/ 418690 (Accessed 4 June 2014)

[11] Choi HM, Lim SY. Fatty acid composition and antiproliferative activity of extracts from Euphorbia supine. J Life Sci 2014; 1: 7480.

[12] Raghuveer C, Tandom RV. Consumption of functional food and our health concerns. Pak J Physiol 2009; 5: 76-83.

[13] Turrents JF. Mitochondiral formation of reactive oxygen species. J Physiol 2003; 552: 335-44.

[14] Amin A, Yazdanparast R. Antioxidant and free radical-scavenging potential of Achilleas antolina extracts. Food Chem 2007; 104: 219.

[15] Cheseman KH, Slater TF. Free radicals in medicine. Br Med Bull 1993; 49: 566-76.

[16] Lebel CP, Ischiropoulos H, Bondy SC. Evaluation of the probe 2',7'-dichlorofluorescin as an indicator of reactive oxygen species formation and oxidative stress. Chem Res Toxicol 1992; 5: 227-31.

[17] Nugroho A, Rhim TJ, Choi MY, et al. Simultaneous analysis and peroxynitrite-scavenging activity of galloylated falvonoid glycosides and ellagic acid in Euphorbia supina. Arch Pharm Res 2013; 29. Published online doi 10.1007/s12272-013-0307-z (Accessed 15 March)

[18] Heo SI, Hu W, Han W, Wang MH. Antioxidant activity and cytotoxic effect of extracts from Euphorbia humifusa. Kor J Pharmacogn 2008; 39: 295-9.

[19] Kim SY, Won DH, Lim MS, Park SM. Cellular protective effect and component analysis of Euphorbia humifusa extracts. Kor J Pharmacogn 2010; 41: 264-9.

[20] Farhan H, Rammal H, Hijazi A, et al. Chemical composition, and antioxidant activity of a Lebanese plant Euphorbia macroclada schyzoceras. Asian Pac J Trop Biomed 2013; 3: 542-8.

Received: March 21, 2014

Revised: June 26, 2014

Accepted: July 04, 2014

(C) Choi and Lim; Licensee Bentham Open.

This is an open access article licensed under the terms of the Creative Commons Attribution Non-Commercial License (http://creativecommons.org/licenses/by-nc/3.0/) which permits unrestricted, non-commercial use, distribution and reproduction in any medium, provided the work is properly cited. 